\title{
Democracy, Governance and Economy: How EaP States Have Evolved in the Last Decade?
}

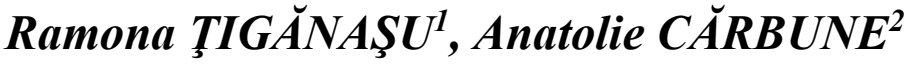

\begin{abstract}
In the last decade, several transformations have occurred at the level of governance systems within the six states included in the Eastern Partnership (Armenia, Azerbaijan, Belarus, Georgia, Moldova, Ukraine), in order to respond to multiple challenges, either endogenous, or exogenous. Against this background, the question that arises is whether this reconfiguration of the systems meant positive effects or, on the contrary, on certain directions, an involution can be highlighted. Thus, our methodological approach takes into account a multidimensional perspective related to democracy, governance and socio-economic aspects, which emphasize whether progress has been made in 2020, compared to 2010, in terms of the mentioned components. The research results underline if the measures implemented by these countries were in accordance with the pro-market and pro-democracy principles, based on good governance. In addition, the identification of some vulnerabilities might allow the outlining of policy recommendations, for an increased adaptability of these economies to future crises.
\end{abstract}

Keywords: democracy, governance, economy, Eastern Partnership countries, dynamics

JEL codes: E02, O20, O47

\section{The Eastern Partnership initiative: background, developments and challenges}

The European Union (EU) launched the European Neighbourhood Policy (ENP) as an innovative tool to build political and economic ties with

\footnotetext{
${ }^{1}$ Ramona ȚIGĂNAŞU is researcher PhD at the Alexandru Ioan Cuza University of Iasi, Faculty of Law - Centre for European Studies, Romania; e-mail: ramona.frunza@uaic.ro. ORCID: 0000-0002-5921-7023

2 Anatolie CĂRBUNE is $\mathrm{PhD}$ candidate at the Alexandru Ioan Cuza University of Iasi, Faculty of Economics and Business Administration, Romania; e-mail: anatoliecarbune@yahoo.com. ORCID: 0000-0002-1649-5779
} 
the new neighbours gained in the aftermath of the enlargement wave in 2004. The EU was seeking to promote its rules and norms among its neighbours in order to foster stability and prosperity, as well as to share the benefits of the enlargement, better described as "sharing everything with the Union but institutions" (European Commission, 2002, p.5). However, due to a mixed response received from the ENP countries and the subsequent worrisome security trends triggered by the Russian-Georgian war in August 2008, the EU concerns towards its eastern neighbourhood translated in a need to boost its presence in this area. Against this background, the EU established the Eastern Partnership (EaP), designed as the eastern dimension of its ENP.

The EaP is a joint initiative aiming at building closer cooperation between the EU and its six neighbours - Ukraine, Moldova, Belarus, Georgia, Armenia and Azerbaijan. Launched at the Prague Summit in 2009, the EaP initiative has been the outcome of the EU acknowledging the need to adapt to a new emerging reality in the eastern neighbourhood (Korosteleva, 2011). In light of this new reality, the EaP has been defined as a strategic partnership based on common values, mutual interests and shared responsibility as key elements embedded within the EU approach towards its partners, as clearly stipulated within the Declaration from Prague officially establishing the EaP (Council of the European Union, 2009). In the same year, the EaP Civil Society Forum was founded, in order to consolidate the multilateral framework, particularly as a platform to promote people-to-people contact and to enhance the dialogue between civil society and public authorities, but also to make citizens' voice heard at international level.

An important milestone of the EU-EaP cooperation was reached in 2014, when the EU concluded the Association Agreements and Deep and Comprehensive Free Trade Areas (AA/DCFTAs) with Georgia, Ukraine and the Republic of Moldova, with the purpose of further fostering economic integration and political association (ENP review, 2015). The agreements aim at enhancing convergence between $\mathrm{EU}$ and $\mathrm{EaP}$ states, by aligning the standards and legislation of the latest to the EU. A tangible contribution of the agreements has been the implementation of the Visa liberalisation, that entered into force for Moldova in 2014, while for Ukraine and Georgia, in 2017.

Despite broadening the EU outlook towards cooperation with the EaP countries, a series of external shocks, particularly the Ukrainian crisis from 
2014, coupled with internal fragilities, pushed the EU to rethink its role in the eastern neighbourhood. Thus, the EU performed a review of the ENP in 2015, followed shortly by the publication of the European Union Global Strategy (EUGS) in 2016. The EU provided a new impetus to its external presence, by designing strategies, policy initiatives and foreign instruments through the lens of building resilience, as a novel policy objective to approach the growing instability in the eastern neighbourhood. The ENP review from 2015 emphasized particularly the need for greater ownership and differentiation in the EU's approach towards its eastern neighbours. In practice, this new approach translated in more tailored policies towards cooperation with Armenia, Azerbaijan and Belarus.

A new milestone for the EU-EaP has been reached in November 2017 at the EaP Summit with the adoption of the " 20 deliverables for 2020 ", aiming at further enhancing convergence and building resilience based on a comprehensive agenda covering the areas of economy, governance, connectivity and society. The EU and Azerbaijan initiated negotiations on a new framework agreement. In the same year, EU and Armenia signed the Comprehensive and Enhanced Partnership Agreement (CEPA), which entered into force on 1 March 2021 (EU Neighbours East, 2021). The EU relations with Belarus include technical dialogue on specific issues, agreements on visa facilitation, which have been applied since on 1 July 2020, and enhanced cooperation towards promoting reforms (European Council, 2021). The next section aims to further explore the key components within EU policy, precisely those related to governance, security/democracy and macroeconomic development, highlighting on the one hand, the achievements and measures implemented, while, on the other hand, the main challenges currently facing EaP states. Then, in the following sections it will be emphasized, by reference to the specialized literature, if the economic convergence can be a sign of resilience in the eastern neighborhood and if the six countries that are the subject of our analysis have known progress on democracy, governance, and economy, in 2020 compared to 2010. The last section of the paper is dedicated to the final remarks, which outline some policy recommendations for strengthening the capacity of EaP states to cope better with future stressors. 


\section{Building stability in the EaP region through good governance, rule of law and security}

Particularly since the ENP review in 2015, the EU interests in terms of enhancing regional stability and security in the eastern neighbourhood were outlined in a more concrete and explicit fashion. In this regard, the EU has expressed its commitment to "promote democratic, accountable and good governance, as well justice reform, rule of law and fundamental rights" (ENP review, 2015, p.3). Furthermore, the security dimension gained more prominence, as it has been framed as a key driver for EaP countries' resilience and linked with the objective of boosting institutional resilience (European Commission, 2017). Both, the EaP countries and EU member states, particularly because of the Ukrainian crisis and the ensuing impact on regional stability, stressed the need for a stronger focus on security. In order to fulfil the objectives on security matters, the EU has established country tailored missions aiming at enhancing the rule of law and promoting cross border cooperation, especially through the EU Monitoring Mission in Georgia (EUMM), the EU Advisory Mission in Ukraine (EUAM) and the EU Border Assistance Mission in Moldova and Ukraine (EUBAM) (European Commission, 2017). The EU missions can be seen as practical expression of building resilience, mainly as preventive measures towards potential crisis. However, resilience was contextualised as a means towards achieving security and stability, but not as goal per se (Petrova and Delcour, 2020). The EU was aiming at scaling up its efforts towards boosting security through a more adaptive approach, which reflects, inter alia, the application of differentiation principle in the EU's policies. Another innovation brought by the ENP review and further advanced by the EUGS was the objective of building societal resilience, as a means for ensuring political and social integration, encouraging and facilitating political participation, which in turn would generate the stability of democratic institutions. As such, the EUGS emphasized the importance of "people-to-people contacts" and boosting the dialogue with various actors and "human rights defenders" (EUGS, 2016, p.25). Thus, enhancing the societal dimension appears clearly as a step forward in comparison with the ENP review from 2011 (Petrova and Delcour, 2020). 
Strengthening governance within the EaP countries with specific focus on rule of law and promoting key reforms in justice represents a condition towards regional stability (EUGS, 2016; European Commission, 2020a). The Association Agreements (AAs) signed in 2014 with Ukraine, Moldova and Georgia are the main bilateral instruments to sustain reforms and to facilitate legal approximation to the Union's acquis, particularly based on a comprehensive package, encompassing rule of law, justice and enhancing public administration. In light of the EaP 10 anniversary in 2019, the European Economic and Social Committee (EESC) concluded that implementing the AA/DCFTA was challenging throughout the decade especially regarding the rule of law and implementation of judicial reforms (EESC, 2019). Furthermore, the EESC emphasized the need to "scale up efforts to strengthen institutions and good governance", which were framed as "preconditions for ensuring long-term stability and an investment-safe climate" (EESC, 2019, p.5).

Referring to the effectively implementing reforms in the fields of justice and rule of law in the EaP countries, mainly in Ukraine, Moldova and Georgia, the progress is characterized by rather an intermittent evolution. Ukraine has experienced some important political development in the mentioned areas, particularly throughout 2018-2019, by enhancing cooperation between the National Anti-Corruption Bureau of Ukraine (NABU) and the Specialised Anti-Corruption Prosecutor's Office (SAPO) (European Commission, 2020b). According to the AA Implementation Report from 2019, public administration reforms continued in Moldova, with specific focus on reorganisation of subordinated institutions (European Commission, 2019, p. 4). However, the picture looked rather grey in the field of human rights protection and enhancing public administration, with delays in implementing the necessary legislation. This is confirmed by various ranking among countries. According to the Global Competitiveness Report 2018, Moldova was ranked 132th out of 140 countries, while the 2019 Rule of Law Index of the World Justice Project, ranked Moldova on the 97th position (out of 126) on criminal justice and on the 87th on civil justice (European Commission, 2019, p.7). Towards the end of first EaP decade, for Georgia the overall context seemed more optimistic, as it has committed to further continue the implementation of the EU acquis. However, challenges 
remain in the areas of electoral reform and reconfiguration of the judiciary (European Commission, 2020c).

\section{Economic convergence in the eastern neighbourhood as a sign of resilience?}

Economic and social development are key policy objectives aiming at bringing stability in the eastern neighbourhood. In this regard, particularly after the ENP review, the EU has put strong emphasis on boosting macroeconomics stability, promoting structural reforms, mainly in the area of economic governance, based on close coordination with international financial institutions (IFIs) (European Commission, 2017). Furthermore, designing sound economic policies coupled with creating a level playing-field for investments and business have been framed as keys towards boosting economic development and generating jobs. According to the World Bank Doing Business Reports, throughout the period of 2014-2020, all EaP countries have implemented concrete measures in order to make starting a business easier by removing some legislative burdens, advanced towards resolving insolvency, enforced contracts, made the payment of taxes easier, as well as effectively strengthen minority investors (The World Bank, 2020). Implementing effective measures within the regulatory environment has been linked with improving the investments and business climate. Furthermore, the EU has set out as a priority to steer the alignment of policies regarding improving the business climate with the 10 principles of the Small Business Act (SBA), which includes, inter alia, boosting the quality of public and private dialogue, increasing the access to services and facilitating access to finance for small companies (European Commission, 2017).

In terms of financial cooperation, the European Neighbourhood Instrument (ENI) was the main financial instrument during 2014-2020 period. Since 2009, "over 125,000 SMEs benefited from direct support from the EU in the EaP countries, which created and sustained 250,000 jobs", a target reached particularly due to improving financial instruments (European Commission, 2020a, p.6). Since 2014, Ukraine has been the main EU beneficiary within the framework of ENI, receiving $€ 1,365$ particularly towards promoting reforms and boosting governance capacity (EEAS, 2020). 
Moreover, Ukraine received $€ 3.8$ billion to develop its economic sector, through Macro-Financial Assistance, being the largest amount directed to any external partner (EEAS, 2020; Chaban and Elgström, 2021, p.145). However, overall since 2014, the EU, together with European financial institutions, have provided with over $€ 16.5$ billion to support reforms in Ukraine. These financial resources have essentially helped to reduce intra- and inter-regional development gaps. Although there is a heterogeneity in terms of growth rates of territories in EaP countries, the ultimate goal of reforms is to ensure a certain degree of convergence in all dimensions of an economy (institutional, democratic, economic, etc.). Starting from these aspects, it is interesting to see if in the case of EaP states there was a convergence at the level of the mentioned components, especially after 2010, when the EU support instruments were expanded. A potential convergence might show to what extent the EU's objectives have been translated in concrete change in $\mathrm{EaP}$ countries' economies, which in turn would signal enhanced regional stability as well.

Whether economic performance of the EaP countries was positively influenced by the EU actions has been in the attention of many scholars. Looking in retrospect, after the fall of the Soviet Union, the EaP countries experienced a quick recovery, an evolution more obvious during 2000s, which has been the outcome of effective implementation of structural reforms (Iradian, 2007). Throughout 1991-2006, the EaP countries have shown a convergence, particularly because of internal market-oriented reforms and external favourable evolutions (Incaltarau et al., 2021). Based on an analysis applied on 1989-2007 period, Gerry et al. (2010) have shown that institutions and good governance particularly influenced macroeconomic stability generating economic growth, which has manifested in regional convergence. A similar conclusion was reached also by Hakimov (2010). The importance of institutions for economic growth, particulalry for economies in transition is recognised in the literature, as a driver of macroeconomic stability and for generating reforms (Acemoglu and Robinson, 2012; Acemoglu et al., 2004). Furthermore, based on an empirical analysis, Coll (2013) performed a classification of the EU member states and the ENP countries - by displaying the GDP per capita from a dynamic point view - covering the period of 1995 2009. Coll's findings show a rather optimistic outlook towards the similarities 
between the EU bloc and the ENP states based on the macroeconomic evolution, emphasizing a convergence within the EaP group as well. Kharlamova (2015) reached a different conclusion, highlighting that the economic growth of the ENP countries followed divergent paths, based on an empirical analysis covering the period of 2000-2014 particularly looking at the provision of the EU funds through thematic programmes. Other authors (Socoliuc and Maha, 2019) showed the same divergent evolution of the EaP countries in terms of social, economic and political transformation and its implications for economic resilience. Bergman and Varga (2018) indicated a dual-track approach towards explaining the EU influence on EaP economic development, indicating that incentives to develop trade, as well as applying EU norms. López-Tamayo et al. (2018) linked the implications of developing bilateral dialogue between $\mathrm{EU}$ and $\mathrm{EaP}$ countries respectively, which has generated divergence within the region, mainly because of implementing a differentiated approach. In addition, Pintilescu and Viorica (2019) found that macroeconomic stability had a clear impact on economic resilience, particularly because of unemployment and inflation, while Gylfason et al. (2015) found that institutions and good governance contributed towards stimulating trade between EaP and EU.

Overall, although there are divided opinions in the literature on the resilience capacity of EaP states, it would be relevant to see in which of the components (democracy, governance, economy) there was a convergence that would create the premises for sustainable development. For this reason, in the next section we resorted to such an analysis.

\section{Methodology and data}

The starting point in our methodological approach was to respond to some challenges encountered in EaP countries, from a multidimensional perspective, more precisely to find explanations for the variations in values on different components, although these states have a relatively common past related to political regimes and history. Thus, we constituted three dimensions of research (democratic, governance and socio-economic), each composed of several variables: the first of 7, the second of 5, and the third of 7. The analysis was done in dynamics (2010 versus 2020), to better capture the progress made by $\mathrm{EaP}$ states in terms of the three components. In essence, through this 
research we intend to cover as many aspects as possible that can contribute to the modeling of development trajectories, to identify vulnerabilities and to propose some recovery measures in the medium and long term.

The purpose of our paper is not necessarily to highlight whether the countries that have concluded association agreements with the EU (Georgia, Moldova, Ukraine) have experienced positive oscillations in terms of democracy, governance or socio-economic issues, compared to those more under the influence of Russia, but rather to see which of these dimensions need more support from decision-makers so that the road to stability and prosperity to be a favorable one.

When it comes to EaP countries, an important limitation of the research is that related to the availability of data. Although there are some official statistics that provide the situation in this area, they are fragmented, not covering a wide range of variables, many values being reported after 2015, but not including all EaP states (e.g., the Index of Public Integrity developed by European Research Centre for Anti-Corruption and State-Building in Berlin, where lacks Armenia and Belarus), which makes it difficult to have an integrative approach. The collection of data was done from various sources, such as: Eurostat statistics, The Fund for Peace, The Bertelsmann Stiftung's Transformation Index, etc. The data extracted from the mentioned sources combine qualitative expert survey, opinion polls, with content analysis and qualitative input, the latter being imputed, not infrequently, a certain degree of subjectivity. Thus, in the component associated with democracy we have included indicators that refer to political participation, stability of democratic institutions, political and social integration, security apparatus, state legitimacy, fundamental human rights and their protection, the influence and impact of external intervention in the functioning of a state. In the governance chapter were included the rule of law, steering capability (prioritization, implementation, policy learning), resource efficiency (efficient use of assets, policy coordination, anti-corruption policy), consensus-building (consensus on goals, conflict management, civil society participation, reconciliation), international cooperation (effective use of support, credibility, regional cooperation). Regarding the socio-economic dimension, this incorporates variables that take into account: income inequalities, education expenditures, the brain drain phenomenon, youth 
unemployment rate, labor productivity, quality of public services, GDP. Most of the variables were measured on a scale of $0-10$, the tendency to register higher values meaning a certain progress (exceptions to this scale include some socio-economic indicators such as GDP, unemployment rate, labour productivity, etc.). All the indicators used in analysis are found in Annex 1, in which the correlation coefficients between them are exposed.

\section{Results and discussion}

Looking at the dynamics, although some progress has been made towards the elements included in our analysis, the fragility of the EaP states from an economic, social, institutional or democratic point of view is still noticeable, this being even more obvious after the appearance of some crises. Large-scale implications were felt through the installation of exogenous shocks, and a severe destabilization of the systems was registered at the time of the Ukrainian Revolution, in 2014. With all the tensions in the area, as a whole, in recent years, EaP countries it is, on average, on an ascending slope in terms of gap recovery, although it should be mentioned that this transformation trend is quite modest, as the descriptive statistics in Table 1 suggest. Thus, it is found that in 2020 there was a slight decrease of discrepancies in line with governance dimension, compared to 2010 $\left(\right.$ Mean $_{2010}=4.991$ and Mean $\left._{2020}=5.404\right)$, the minimum value in 2010 being 3.600 , and in 2020, 4.190. At the same time, the maximum value registered a modest increase (from 6.090 in 2010 to 6.530 in 2020). This component of governance seems to be in close connection with the impact of the Eastern Partnership, in terms of expanding EaP cooperation with the EU, aligning with some European standards, using EU funds, enforcing the rule of law and building a general consensus on solving internal problems. The leap, although not a significant one, denotes an involvement of decision makers in finding solutions to the domestic challenges, so that governance is based on dialogue, collaboration between all actors for rational use of resources, according to societal needs. Without a change of register regarding governance, it is not possible to move forward either from an economic or democratic point of view and EaP countries have become aware of this in recent years. 
Table 1. Descriptive statistics

\begin{tabular}{|c|c|c|c|c|c|c|c|c|}
\hline \multicolumn{5}{|c|}{2010} & \multicolumn{4}{|c|}{2020} \\
\hline & Min. & Max. & Mean & $\begin{array}{c}\text { Std. } \\
\text { deviati } \\
\text { on }\end{array}$ & Min. & Max. & Mean & $\begin{array}{c}\text { Std. } \\
\text { deviat } \\
\text { on }\end{array}$ \\
\hline $\begin{array}{l}\text { Political } \\
\text { participation }\end{array}$ & 2.750 & 7.750 & 5.250 & 2.174 & 2.250 & 8.250 & 5.875 & 2.659 \\
\hline $\begin{array}{l}\text { Stability of } \\
\text { democratic } \\
\text { institutions }\end{array}$ & 2.000 & 7.000 & 4.333 & 2.563 & 2.000 & 7.500 & 5.250 & 2.382 \\
\hline $\begin{array}{l}\text { Political and } \\
\text { social } \\
\text { integration }\end{array}$ & 3.330 & 6.000 & 4.806 & 1.101 & 2.670 & 6.000 & 4.722 & 1.295 \\
\hline $\begin{array}{l}\text { Security } \\
\text { apparatus }\end{array}$ & 3.800 & 8.000 & 6.367 & 1.662 & 5.200 & 6.980 & 5.807 & 0.645 \\
\hline $\begin{array}{l}\text { State } \\
\text { legitimacy }\end{array}$ & 6.600 & 9.000 & 7.900 & 0.899 & 6.000 & 9.100 & 7.633 & 1.239 \\
\hline Human rights & 5.300 & 7.900 & 6.817 & 0.898 & 4.800 & 8.000 & 6.317 & 1.248 \\
\hline $\begin{array}{l}\text { External } \\
\text { intervention }\end{array}$ & 5.800 & 8.700 & 7.133 & 0.971 & 5.900 & 8.100 & 6.683 & 0.796 \\
\hline $\begin{array}{l}\text { DEMOCRAT } \\
\text { IC } \\
\text { DIMENSION }\end{array}$ & 5.030 & 7.360 & 6.087 & 0.941 & 5.120 & 7.030 & 6.041 & 0.773 \\
\hline Rule of law & 3.000 & 6.250 & 4.833 & 1.221 & 3.000 & 6.250 & 5.000 & 1.369 \\
\hline $\begin{array}{l}\text { Steering } \\
\text { capability }\end{array}$ & 3.330 & 6.000 & 4.667 & 1.011 & 4.000 & 6.330 & 5.444 & 0.861 \\
\hline $\begin{array}{l}\text { Resource } \\
\text { efficiency }\end{array}$ & 4.000 & 6.670 & 4.667 & 1.033 & 3.670 & 6.670 & 5.111 & 1.089 \\
\hline $\begin{array}{l}\text { Consensus- } \\
\text { building }\end{array}$ & 3.000 & 6.400 & 4.733 & 1.231 & 3.600 & 6.800 & 5.300 & 1.384 \\
\hline $\begin{array}{l}\text { International } \\
\text { cooperation }\end{array}$ & 4.000 & 6.670 & 6.056 & 1.042 & 5.000 & 7.330 & 6.167 & 0.863 \\
\hline $\begin{array}{l}\text { GOVERNAN } \\
\text { CE } \\
\text { DIMENSION }\end{array}$ & 3.600 & 6.090 & 4.991 & 0.907 & 4.190 & 6.530 & 5.404 & 1.031 \\
\hline $\begin{array}{l}\text { Economic } \\
\text { inequality }\end{array}$ & 6.200 & 7.300 & 6.783 & 0.417 & 3.300 & 5.200 & 4.100 & 0.693 \\
\hline $\begin{array}{l}\text { Brain drain } \\
\text { phenomenon }\end{array}$ & 4.800 & 7.800 & 6.283 & 1.067 & 3.700 & 7.000 & 5.366 & 1.260 \\
\hline Public services & 4.000 & 6.700 & 5.683 & 0.983 & 3.300 & 4.710 & 3.872 & 0.631 \\
\hline $\begin{array}{l}\text { Public } \\
\text { expenditure on } \\
\text { education } \\
\text { (\%GDP) }\end{array}$ & 2.800 & 7.700 & 4.633 & 2.171 & 2.000 & 5.500 & 4.017 & 1.427 \\
\hline
\end{tabular}




\begin{tabular}{|c|c|c|c|c|c|c|c|c|}
\hline GDP & $\begin{array}{c}50.20 \\
0\end{array}$ & $\begin{array}{c}108.40 \\
0\end{array}$ & $\begin{array}{c}84.38 \\
3\end{array}$ & 20.822 & $\begin{array}{c}67.50 \\
0\end{array}$ & $\begin{array}{c}98.60 \\
0\end{array}$ & $\begin{array}{c}85.03 \\
3\end{array}$ & 13.574 \\
\hline $\begin{array}{l}\text { Unemploymen } \\
\text { t rate_15 to } 24 \\
\text { years }\end{array}$ & $\begin{array}{c}14.90 \\
0\end{array}$ & 38.900 & $\begin{array}{c}25.15 \\
0\end{array}$ & 10.697 & $\begin{array}{c}10.40 \\
0\end{array}$ & $\begin{array}{c}32.60 \\
0\end{array}$ & $\begin{array}{c}18.78 \\
3\end{array}$ & 10.014 \\
\hline $\begin{array}{l}\text { Labour } \\
\text { productivity in } \\
\text { GDP (constant } \\
\text { prices) per } \\
\text { person } \\
\text { employed }\end{array}$ & $\begin{array}{c}- \\
0.600\end{array}$ & 7.200 & 3.917 & 2.572 & 0.600 & 5.400 & 1.950 & 1.747 \\
\hline $\begin{array}{l}\text { SOCIO- } \\
\text { ECONOMIC } \\
\text { DIMENSION }\end{array}$ & $\begin{array}{c}12.86 \\
0\end{array}$ & 23.100 & $\begin{array}{c}19.54 \\
8\end{array}$ & 3.965 & $\begin{array}{c}13.94 \\
0\end{array}$ & $\begin{array}{c}20.77 \\
0\end{array}$ & $\begin{array}{c}17.58 \\
9\end{array}$ & 2.814 \\
\hline
\end{tabular}

Source: authors' estimates

Regarding the democratic dimension, it can be easily observed that in ten years there have been no changes in the sense of improving security, aspects of legitimacy, institutional stability, defense of fundamental rights and the correct conduct of elections $\left(\operatorname{Mean}_{2010}=6.087\right.$ and $\left.\operatorname{Mean}_{2020}=6.041\right)$, all these being eroded by a series of destabilizing events, which deepened the population's dissatisfaction even more. In socio-economic terms, the case of Ukraine is highlighted in the context of the 2014 event, when post-shock growth rates are clearly influenced in the sense of making the macroeconomic climate more vulnerable. Overall, most EaP countries have experienced the effects of the Ukrainian conflict, and their GDP has been affected and in our analysis the values of socio-economic dimension strengthen this statement $\left(\operatorname{Mean}_{2010}=19.548\right.$ and $\left.\operatorname{Mean}_{2020}=17.589\right)$. However, situations where states with high migration flow have seen slight increases in income due to remittances should not be overlooked (for example, the Russian labor market has provided 11.4\% of GDP for Ukrainian workers in 2020, according to BTI data). Against the background of Russia's internal structural problems, regulations related to immigrants have tightened, which will lead to an alteration of these remittances in the future. Within each dimension, among the lowest values in 2010 are found: stability of democratic institutions (2.000) for democratic dimension; rule of law and consensus-building, both with 3.000, for governance dimension; the quality of public services (4.000) for socio-economic dimension. These scores remain relatively constant over 
time, with slight variations in 2020, in the indicators relating to consensusbuilding (3.600) and quality of public services (3.300).

In order to better capture the differences between the EaP states in terms of the dimensions included in the research, we resorted to the nearest neighbor analysis, through which the distances from the best placed country are observed (Table 2).

\section{Table 2. Nearest neighbor analysis (proximity matrix - Euclidean distance)}

\section{Democratic dimension}

\begin{tabular}{|c|c|c|c|c|c|c|c|c|c|c|c|c|c|}
\hline \multicolumn{7}{|c|}{2010} & \multicolumn{7}{|c|}{2020} \\
\hline & ARM & AZE & BLR & GEO & MDA & UKR & & ARM & AZE & BLR & GEO & MDA & UKR \\
\hline ARM & 0.000 & 0.464 & 0.412 & 2.324 & 2.024 & 1.095 & ARM & 0.000 & 1.285 & 1.090 & 0.257 & 0.704 & 0.625 \\
\hline AZE & 0.464 & 0.000 & 0.052 & 1.860 & 1.560 & 0.631 & AZE & 1.285 & 0.000 & 0.195 & 1.542 & 0.581 & 1.910 \\
\hline BLR & 0.412 & 0.052 & 0.000 & 1.912 & 1.612 & 0.683 & BLR & 1.090 & 0.195 & 0.000 & 1.347 & 0.386 & 1.716 \\
\hline GEO & 2.324 & 1.860 & 1.912 & 0.000 & 0.300 & 1.229 & GEO & 0.257 & 1.542 & 1.347 & 0.000 & 0.961 & 0.368 \\
\hline MDA & 2.024 & 1.560 & 1.612 & 0.300 & 0.000 & 0.929 & MDA & 0.704 & 0.581 & 0.386 & 0.961 & 0.000 & 1.329 \\
\hline UKR & 1.095 & 0.631 & 0.683 & 1.229 & 0.929 & 0.000 & UKR & 0.625 & 1.910 & 1.716 & 0.368 & 1.329 & 0.000 \\
\hline
\end{tabular}

\section{Governance dimension}

\begin{tabular}{|c|c|c|c|c|c|c|c|c|c|c|c|c|c|}
\hline & ARM & AZE & BLR & GEO & MDA & UKR & & ARM & AZE & BLR & GEO & MDA & UKR \\
\hline ARM & 0.000 & 0.460 & 1.300 & 1.187 & 0.223 & 0.897 & ARM & 0.000 & 1.907 & 1.907 & 0.437 & 0.833 & 0.077 \\
\hline AZE & 0.460 & 0.000 & 0.840 & 1.647 & 0.683 & 1.357 & AZE & 1.907 & 0.000 & 0.000 & 2.343 & 1.073 & 1.983 \\
\hline BLR & 1.300 & 0.840 & 0.000 & 2.487 & 1.523 & 2.197 & BLR & 1.907 & 0.000 & 0.000 & 2.343 & 1.073 & 1.983 \\
\hline GEO & 1.187 & 1.647 & 2.487 & 0.000 & 0.963 & 0.290 & GEO & 0.437 & 2.343 & 2.343 & 0.000 & 1.270 & 0.360 \\
\hline MDA & 0.223 & 0.683 & 1.523 & 0.963 & 0.000 & 0.673 & MDA & 0.833 & 1.073 & 1.073 & 1.270 & 0.000 & 0.910 \\
\hline UKR & 0.897 & 1.357 & 2.197 & 0.290 & 0.673 & 0.000 & UKR & 0.077 & 1.983 & 1.983 & 0.360 & 0.910 & 0.000 \\
\hline
\end{tabular}

Socio-economic dimension

\begin{tabular}{|c|c|c|c|c|c|c|c|c|c|c|c|c|c|}
\hline & ARM & AZE & BLR & GEO & MDA & UKR & & ARM & AZE & BLR & GEO & MDA & UKR \\
\hline ARM & 0.000 & 9.286 & 4.186 & 0.957 & 0.671 & 3.729 & ARM & 0.000 & 6.830 & 6.514 & 1.500 & 2.099 & 2.153 \\
\hline AZE & 9.286 & 0.000 & 5.100 & 10.243 & 9.957 & 5.557 & AZE & 6.830 & 0.000 & 0.316 & 5.330 & 4.731 & 4.677 \\
\hline BLR & 4.186 & 5.100 & 0.000 & 5.143 & 4.857 & 0.457 & BLR & 6.514 & 0.316 & 0.000 & 5.014 & 4.415 & 4.361 \\
\hline GEO & 0.957 & $\begin{array}{c}10.24 \\
3\end{array}$ & 5.143 & 0.000 & 0.286 & 4.686 & GEO & 1.500 & 5.330 & 5.014 & 0.000 & 0.599 & 0.653 \\
\hline MDA & 0.671 & 9.957 & 4.857 & 0.286 & 0.000 & 4.400 & MDA & 2.099 & 4.731 & 4.415 & 0.599 & 0.000 & 0.054 \\
\hline UKR & 3.729 & 5.557 & 0.457 & 4.686 & 4.400 & 0.000 & UKR & 2.153 & 4.677 & 4.361 & 0.653 & 0.054 & 0.000 \\
\hline
\end{tabular}

Source: authors' estimates 
In 2010, at the dimension related to democracy, the extreme disparity is established between Georgia and Armenia (2.324), and in 2020, between Azerbaijan and Ukraine (1.910). The governance dimension highlights that the biggest differences are, in 2010, on the one hand, between Belarus and Georgia (2.487) and Ukraine and Belarus (2.197), on the other hand; in 2020, the distances between countries decrease slightly, surprising a relative convergence, so that between Georgia, Azerbaijan and Belarus is the highest distance (2.343), followed by that between Ukraine, Azerbaijan and Belarus (1.983). In the socio-economic direction, in 2010 there are the largest gaps between Georgia and Azerbaijan (10.243) and between Azerbaijan and Moldova (9.957), and in 2020 between Armenia and Azerbaijan (6.830) and between Belarus and Armenia (6.514). The dynamics of economic transformation are not limited to concluding associations or free trade agreements with EU, but rather it is related to internal stability, the existence of a favorable framework for social inclusion, the identification of weaknesses and the rethinking of development strategies in line with the territorial characteristics. Therefore, a multitude of factors can shape the evolution paths of a country, not being relevant only a particular component (for example, if we were to refer to Azerbaijan, that exports gas and oil, it has not taken important steps towards growth, despite the significant increase in crude oil prices).

If the socio-economic dimension can experience faster variations depending on the degree of adaptability of systems to the ever-changing contexts and development strategies put into practice, in terms of governance, there is a growing influence of past models, history, institutional configurations, social dynamics, political visions, aspects related to the cultural imprint, which prove to be more difficult to change. Some values or attitudes change easily when there is interest to do so, while others do not evolve and they are simply unchangeable. In neo-institutionalism approaches, the starting point consists in the individual's perception of a value and the attitude on a problem which are likely to change through the mechanism of imitation (Mantzavinos, 2006); people will imitate a specific behaviour and will find proper tools to achieve it if this supposes a better life satisfaction. In this way, the collective unconscious determines a new approach to solve an existential issue that will lie at the basis of institutional innovation. However, in order to reach institutional innovation, an incompatibility between new formal institutions 
(regulations, laws, contracts), which will be adopted, and the old informal ones, inherited from the past, should not be so obvious to hinder the absorption of shocks. In countries where mentality change has occurred, new regulations can be easily embraced. If, on the contrary, the diffuse support of informal institutions or value systems does not exist, then the new institutions are seen as not having great relevance for development, their integration in the social practice being more difficult (Sedlacek and Gaube, 2010). In essence, territories that share similar value systems also have a mutual trust, and the level of cooperation is high. In the case of EaP states, the path dependency process should be noted, the initial conditions, which may cause informal institutions to prove to be an obstacle towards competitiveness, if they are not effectively combined with the formal ones, drawn in the spirit of democracy, good governance and economic progress. However, the efforts made in the direction of ensuring a certain convergence should not be omitted, a fact that is captured in the plots in Figure 1.

If in 2010 a distance of countries is observed in terms of the analyzed dimensions, in 2020 they come closer together, forming a relatively homogeneous cluster, the differences diminishing to some extent. Looking at the components of each dimension, there is a regrouping of them, in particular the governance knowing positive variations. For a clearer highlighting of the interconditionalities between the variables subject to our analysis, we set out in Annex $1 a$ and Annex $1 b$, the correlation coefficients, according to which we find that, in 2010, the strongest links are established between the democratic dimension and that of governance $(0.672)$, followed by the relationship between democracy and socio-economic dimension (0.529), respectively between governance dimension and socio-economic one (0.505).

If we refer to the strongest influences that the constituent elements have on the three dimensions, it is emphasized that the greatest determinism on the democratic dimension has the indicator stability of democratic institutions (0.893), on the governance dimension has steering capability (0.969), and $G D P$ has on socio-economic dimension (0.965). Instead, in 2020, the dashboard is as follows: between democratic dimension and governance one is established a very close connection (0.944), between democratic dimension and socio-economic one, the conditionality is $79.4 \%(0.794)$, and between governance dimension and socio-economic one, the influence is also very 
high (0.911). Looking inside the democratic dimension, it is observed that the greatest determinism has the stability of democratic institutions (0.923), on the one related to governance it has rule of law (0.960), and on the socioeconomic one it has GDP (0.868).

Figure 1. The dynamics of EaP countries in terms of democratic, governance and socio-economic dimensions (2010 versus 2020)
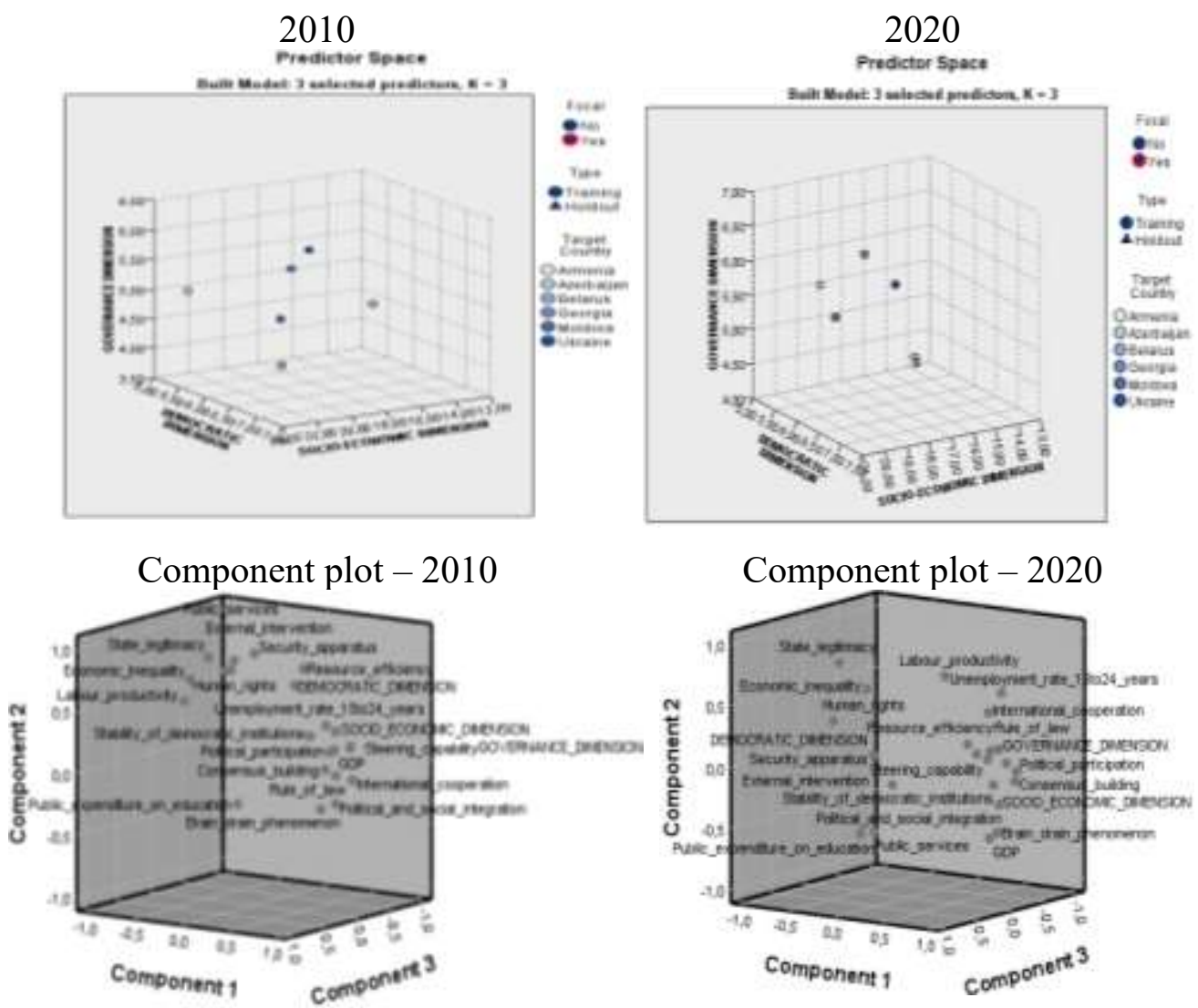

Source: authors' representation

Thus, on the whole, if actions are taken in a country in order to create institutional stability, ensure and respect the rule of law, adapt measures to needs and implement policies based on lessons learned from the past, the context of economic development can be generated. Broadly speaking, it is found that the three dimensions are interconnected, a weakness of one causing 
negative effects on the others. Through the cluster analysis, in Figure 2 it can be seen how the EaP states are grouped according to the dimensions of the research (2010 compared to 2020).

\section{Figure 2. Cluster analysis - grouping EaP countries according to the dimensions considered in the analysis}

2010

Democratic

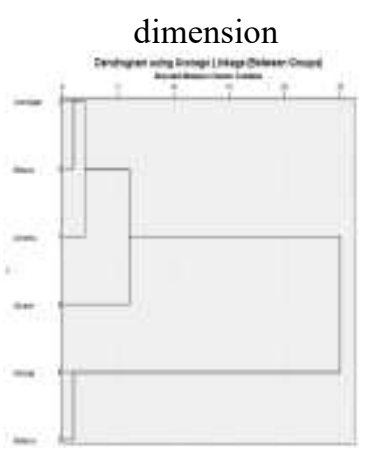

Democratic dimension

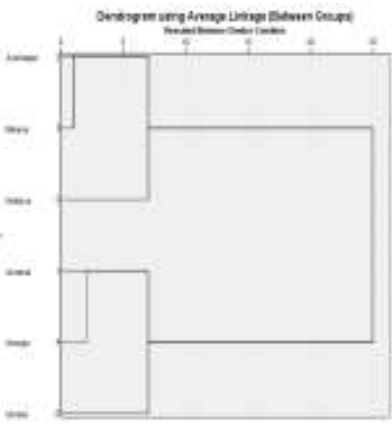

Governance dimension

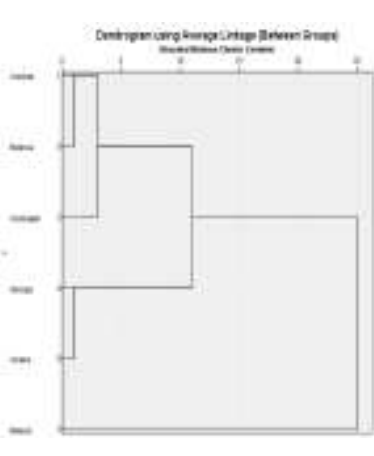

2020
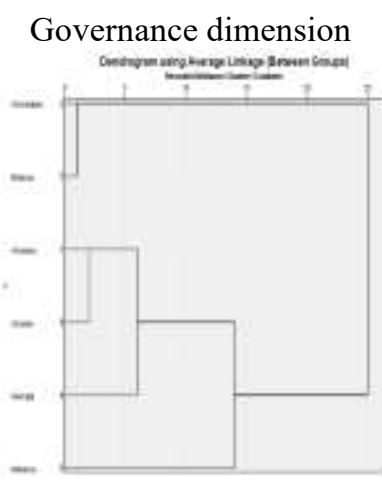

Socio-economic dimension

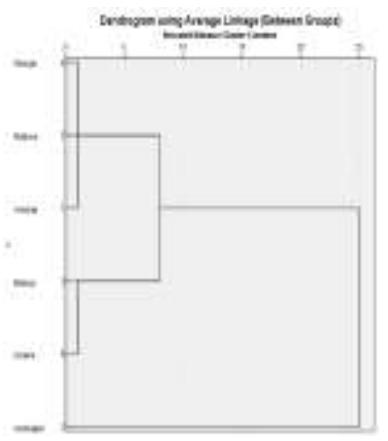

Socio-economic dimension

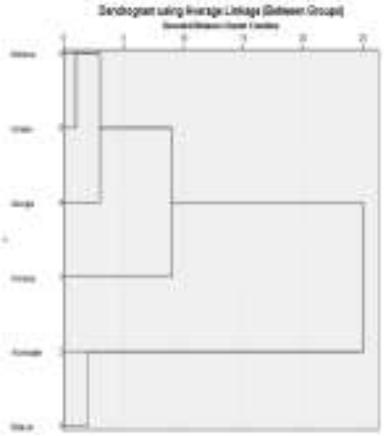

Source: authors' representation

In terms of democratic dimension, it is emphasized that both in 2010 and 2020, Azerbaijan and Belarus obtained relatively equal scores, being included in the same cluster. Referring to Armenia, this has faced systemic vulnerabilities over time, deepened by excessive control of the oligarchic powers over the economic environment and the media, but with the December 2018 parliamentary elections and the formation of the new government in 
January 2019, it seems to have tried a change of register, by supporting the promarket and pro-democracy ideas, their promoters being generally young people. It remains to be seen whether this new paradigm will reposition Armenia in the direction of ensuring decision-making transparency, reducing bureaucracy and increasing the quality of life. The mass protests usually start against the background of shortcomings felt by the majority of the population, which indicates that in the case of Armenia, the Velvet Revolution of 2018 meant exactly the point of saturation generated by instability (Terzyan, 2019). Regardless of the geopolitical orientation, the closeness to Brussels or Moscow, in some of the EaP states (Moldova, Ukraine) there have been actions aimed at fraudulent elections, which emphasizes the particular interests of groups that put personal advantages above the welfare of the nation.

To make the system shock-resistant it is necessary to reorganize, to provide elastic structures on all levels, focus on country-specific priorities, monitor and coordinate macroeconomic policies, strengthen the rule of law, absorb good practices, in other words, an integrated approach could facilitate the move towards competitiveness and towards finding a new identity (Drăgan, 2015). The instruments through which these aspects can be achieved refer, on the one hand, to domestic financial support and, on the other hand, to the support of international bodies. In this context, we recall the case of the EU, which, through ENP, has addressed, in recent years, joint operational programs (JOP) aimed at supporting cross-border cooperation and development of border regions (i.e., European Neighborhood Policy Instrument). Even if previous programming periods have highlighted the fact that these funds are not sufficient to reduce economic peripherality or to solve the internal problems, they are still an important step in the field of cross-border cooperation.

\section{Conclusions}

The research results show that although there are disparities between the six EaP states in terms of the three dimensions (democratic, governance, socio-economic), they can be reduced if coherent measures are implemented, aimed at promoting democratic values, supporting good governance and encouraging the economy by investing in education, in order to reduce brain drain phenomenon, unemployment and social inequality. Although the 
discrepancies did not decrease significantly in 2020, compared to 2010, there are, however, on average, positive dynamics, with a certain convergence, given especially by the awareness of alignment to norms and rules in the service of justice, rule of law, judicial independence, essential criteria in the context of the Europeanization process. The quality of institutions, corruption control, participatory management, accountability, reactivity, transparency are the elements often cited when measuring good governance. Therefore, the fight against corruption is required to be a first measure to recover the economies of these countries, along with ensuring the diversification of economic activities and institutional adaptability. At the same time, the endowment with production factors and resources has a special relevance in the growth process. Moreover, it should be emphasized that the development paths of the six states under analysis are strongly shaped by the expression "history matters", and getting rid of the Soviet Union's influence is still a great challenge. The existence of clear directions of action, in accordance with the principles of democracy, without capturing the State by a part of the population, without the impregnation of oligarchic power structures on almost all levels, and strengthening cooperation between actors, would ensure the premises for an increased resistance to shocks, including for the peripheral territories of EaP countries. A balanced and inclusive growth envisages a multidimensional approach, not a fragmented one. Fragility in a certain sector can cause oscillations, most likely in a negative sense, in other sectors.

From a policy-making outlook, our research indicates that in order to support progress within the EaP framework, addressing topics related to the democratic, governance and socio-economic dimensions might be considered of great importance, particularly in countries facing systemic vulnerabilities. In this context, enhancing the multilateral track of the EaP could enable a more accentuated cooperation between the EaP members, an area where the EaP Civil Society Forum could play a stronger role, by providing a platform for dialogue on thematic issues, by better connecting local and international actors. Addressing aspects related to political participation, stability of democratic institutions, as well as boosting social integration could facilitate convergence, as they are displayed as drivers of socio-economic development. In addition, strengthen the governance dimension should gain a major significance within the overall policy framework, as it is a key 
element of macroeconomic climate, as shown by our analysis. As such, stronger application of the EU acquis is needed in the field of governance, as previous research also indicated (Wolczuk et al., 2017). In this regard, empowering citizens, by ensuring effective institutional provisions, as a way to boost political participation, could mean a tool for promoting reforms implementation. This idea was reiterated by Korosteleva, highlighting the relevance of human rights, political participation and fostering development, as a transformational approach to resilience (Korosteleva, 2020). Following this reasoning, the EU support to Ukraine after the Ukrainian crisis can be seen as a notable example.

Our research brings under the spotlight the importance of tailoring policies according to the countries' profiles. In this regard, the introduction of the "differentiation" principle within the ENP review in 2015 contributed towards facilitating the process of tailoring policies and emphasizing a stronger responsability, however, some divergence across the full policy spectrum can be still seen. As such, boosting bilateral dialogue, with stronger focus on states' expectations and needs should be a top priority, in order to bounce back the divergence trends in some countries (e.g., democracy in Ukraine, governance in Armenia or Azerbaijan, especially against the background of the 2020 Nagorno-Karabakh war). This is further underlined by the relevance of international cooperation as a driver of convergence, thus should be taken into consideration within the overall policy-making process as a long-term priority. Revitalizing ownership across the full policy spectrum could be, thus, a solid element for the perspective to look at, considering its limited embeddedness in practice, an issue noticed in the literature as well (Blockmans, 2017; van Gils, 2017).

In a future study we aim to highlight the effects that the Covid-19 pandemic has had on EaP countries, to see if this shock has affected the economic, institutional or democratic level more strongly, compared to other previous shocks, and to underline if these states have the necessary resources to put in place the most appropriate measures so that the speed of recovery to be as high as possible. 


\section{References:}

Acemoglu, D., \& Robinson, J. A. (2012). Why Nations Fail: The Origins of Power, Prosperity and Poverty (1st ed.). New York: Crown.

Acemoglu, D., Johnson, S., \& Robinson, J. (2004). Institutions as the Fundamental Cause of Long-run Growth. Working Paper. No. 10481. National Bureau of Economic

Research. https://doi.org/10.3386/w10481

Bergman, E. M., \& Varga, A. (2018). Innovative potential for development of Europe's neighbouring countries and regions. The Annals of Regional Science, 60(3), 443-449. https://doi.org/10.1007/s00168017-0826-5

Blockmans, S. (2017). The Obsolescence of the European Neighbourhood Policy. CEPS Paperback. October 2017.

Chaban, N., \& Elgström, O. (2021). Politicization of EU Development Policy: The Role of EU External Perceptions (Case of Ukraine). JCMS: Journal of Common Market Studies, 59(1), 143-160.

https://doi.org/10.1111/jcms.13137

Coll, E. (2013). The Classification of EU and Eastern Partnership Countries regarding Economic Development Level - a Dynamic

Approach. Research Papers of Wroc aw University of Economics, 286, 144-156.

Council of the European Union. (2009). Joint Declaration of the Prague Eastern Partnership Summit, Prague. 7 May 2009, Brussels. https://www.consilium.europa.eu/media/

31797/2009_eap_declaration.pdf

Drăgan, G. (2015). Deepening the Economic Integration in the Eastern Partnership: from a Free Trade Area to a Neighbourhood Economic Community? Eastern Journal of European Studies, 6(2), 9-26.

EEAS. (2016). Shared Vision, Common Action: A Stronger Europe. A Global Strategy for the European Union's Foreign and Security Policy. https://eeas.europa.eu/archives/docs/ top_stories/pdf/eugs_review_web.pdf

EEAS. (2020). EU-Ukraine relations - factsheet. 30 September.

https://eeas.europa.eu/

delegations/iran/4081/eu-ukraine-relations-factsheet_en

European Council. (2021). EU Relations with Belarus.

https://www.consilium.europa.eu/

en/policies/eastern-partnership/belarus/

EU Neighbours East. (2021). EU-Armenia Comprehensive and Enhanced Partnership Agreement enters into force. March 1. 
https://euneighbourseast.eu/news-and-stories/

latest-news/eu-armenia-comprehensive-and-enhanced-partnershipagreement-enters-into-force/

European Commission. (2002). A Wider Europe - A Proximity Policy as the Key to Stability. Press release database.

https://ec.europa.eu/commission/presscorner/detail/en/

SPEECH_02_619

European Commission. (2015). Review of the European Neighbourhood Policy. 18 November 2015, Brussels.

https:/eeas.europa.eu/archives/docs/enp/documents/2015/151118_join t-communication_review-of-the-enp_en.pdf

European Commission. (2017). Revised European Neighbourhood Policy:

Supporting Stabilisation, Resilience, Security. Brussels, 18 May 2017. https://ec.europa.eu/

commission/presscorner/detail/en/IP_17_1334

European Commission. (2019). Association Implementation Report on Moldova. 11 September Brussels.

https://eeas.europa.eu/headquarters/headquarters-homepage/67202/

association-implementation-report-moldova_en

European Commission. (2020a). Eastern Partnership Policy beyond 2020.

Reinforcing Resilience - an Eastern Partnership that delivers for all. 18 March, Brussels.

https://eeas.europa.eu/sites/default/files/1_en_act_part1_v6.pdf

European Commission. (2020b, 1 December). Press release: Ukraine: EU report notes continued implementation of the reform agenda though challenges remain. Brussels, 1 December 2020.

https://ec.europa.eu/commission/presscorner/api/files/document/print/ en/ip_20_2259/IP_20_2259_EN.pdf

European Commission. (2020c, $\overline{7}$ February). Press release: Georgia: EU report highlights importance of maintaining reform momentum and depolarising the political environment .

https://ec.europa.eu/commission/presscorner/detail/en/IP_20_172

European Economic and Social Committee. (2019). 10 years of Eastern Partnership: reflecting on achievements and shaping the future policy of the EaP. https://eur-lex.europa.eu/legalcontent/EN/TXT/HTML/?uri=PI_EESC:EESC-2019-02122-

AS\& from $=\mathrm{DE}$

Eurostat. (2021). Eastern European Neighbourhood Policy Countries. (ENPEast). https://ec.europa.eu/eurostat/web/european-neighbourhoodpolicy/enp-east/data/database 
Gylfason, T., Martínez-Zarzoso, I., \& Wijkman, P. M. (2015). Free Trade Agreements, Institutions and the Exports of Eastern Partnership Countries. JCMS: Journal of Common Market Studies, 53(6), 12141229. https://doi.org/10.1111/jcms.12275

Hakimov, D. (2010). Convergence or Divergence: The Analysis of Economic Growth in the CIS Countries [Masters Dissertation, Charles University, Prague]. Charles University Thesis

Repository. https://dspace.cuni.cz/handle/20.500.11956/24426

Incaltarau, C., Sharipov, I., Pascariu, G.C., \& Moga, T.L. (2021). Growth and Convergence in Eastern Partnership and Central Asian Countries since the Dissolution of the USSR - Embarking on Different Development Paths? Development Policy Review. https://doi.org/10.1111/dpr.12547

Iradian, G. (2007). Rapid Growth in the CIS. Panel Regression Approach, Working Paper No. 07/170, IMF Working Papers, 1-42.

https://doi.org/10.5089/9781451867343.001

Kharlamova, G. (2015). The European Union and the Eastern Partnership:

Convergence of Economies, 22nd International Economic Conference, IECS 2015, 15-16 May 2015, Sibiu, Romania.

Korosteleva, E. (2011). The Eastern Partnership Initiative: A New Opportunity for Neighbours? Journal of Communist Studies and Transition Politics, 27(1), pp. 1-21.

https://doi.org/10.1080/13523279.2011.544381

Korosteleva, K. (2020). Reclaiming Resilience Back: A Local Turn in EU

External Governance. Contemporary Security Policy, 41(2), 241-262.

DOI:10.1080/13523260.2019.1685316

López-Tamayo, J., Ramos, R., \& Suriñach i Caralt, J. (2018). Economic

Performance, Social Progress and Institutional Reform in European

Neighbouring Countries, The Annals of Regional Science, 60(3), 613636. https://doi.org/10.1007/s00168-016-0785-2

Mantzavinos, C. (2006). Individuals, Institutions and Markets, Cambridge University Press, Cambridge.

Petrova, P., \& Delcour, L. (2020). From Principle to Practice? The Resilience-Local Ownership nexus in the EU Eastern Partnership Policy. Contemporary Security Policy, 41(2), 336-360. DOI: $10.1080 / 13523260.2019 .1678280$

Pintilescu, C., \& Viorică, D. (2019). Current Methodological Approaches in Economic Resilience Analysis. Empirical Findings in the EaP Countries. In G. Rouet, \& G. C. Pascariu (Eds.), Resilience and the EU's Eastern Neighbourhood Countries, Palgrave Macmillan, Cham (pp. 321-348). 
Sedlacek, S., \& Gaube, V. (2010). Regions on their Way to Sustainability: the Role of Institutions in Fostering Sustainable Development at the Regional Level. Environment, Development and Sustainability, 12(1), 117-134. https://doi.org/10.1007/s10668-008-9184-x

Socoliuc, O.R., \& Maha, L.G. (2019). The Economic Dynamics of the Eastern Partnership Countries: Between Development Gaps and Internal Fragilities, In G. Rouet, \& G. C. Pascariu (Eds.), Resilience and the EU's Eastern Neighbourhood Countries, Palgrave Macmillan, Cham (pp. 321-348).

Terzyan, A. (2019). The Aftermath of the "Velvet Revolution": Armenia between Domestic Change and Foreign Policy Continuity. Eastern European Journal of Regional Studies, 5(2), 24-43,

https://csei.ase.md/journal/files/issue_52/EEJRS

\section{2_f-24-43_TER.pdf}

The Bertelsmann Stiftung's Transformation Index - BTI. (2020) . https://btiproject.org/en/?\&cb=00000

The Fund for Peace. (2021). Fragile States Index. https://fragilestatesindex.org

The World Bank. (2020). World Bank Doing Business Reports. https://www.doingbusiness.org/en/doingbusiness

Van Gils, E. (2017). Differentiation through Bargaining Power in EUAzerbaijan Relations: Baku as a tough Negotiator. East European Politics, 33, 388-405. doi: 10.1080/21599165.2017.1322957

Wolczuk, K., Delcour, L., Dragneva, R., Maniokas, K., \& Zeruolis, D. (2017). The Association Agreements as a Dynamic Framework: between Modernization and Integration, EU-STRAT Working Paper, 6. Berlin: Freie Universität. http://eu-strat.eu/wpcontent/uploads/2017/09/EU-STRAT-Working-Paper-No.-6.pdf

World Economic Forum. (2018). The Global Competitiveness Report 2018. https://www.weforum.org/reports/the-global-competitvenessreport-2018

World Justice Project. (2019). WJP Rule of Law Index 2019. https://worldjusticeproject.org/

our-work/research-and-data/wjp-rule-law-index-2019

Acknowledgement: This research has been conducted with the support of the Erasmus + programme of the European Union, within the Project no. 621262EPP-1-2020-1-RO-EPPJMO-MODULE 2017-2625 'Jean Monnet Module on EU Interdisciplinary Studies: Widening Knowledge for a more Resilient Union (EURES)', co-financed by European Commission in the framework of Jean Monnet Action. 
Annex 1a. Correlation matrix - 2010

\begin{tabular}{|c|c|c|c|c|c|c|c|c|c|c|c|c|c|c|c|c|c|c|c|c|c|c|}
\hline VARIABLES & $\begin{array}{l}\text { Political } \\
\text { participa } \\
\text { tion }\end{array}$ & $\begin{array}{c}\text { Stability } \\
\text { of } \\
\text { demoora } \\
\text { tic } \\
\text { institutio } \\
\text { ns } \\
\end{array}$ & $\begin{array}{c}\text { Political } \\
\text { and } \\
\text { social } \\
\text { integrati } \\
\text { on }\end{array}$ & $\begin{array}{l}\text { Securi } \\
\text { ty } \\
\text { appar } \\
\text { atus }\end{array}$ & $\begin{array}{c}\text { State } \\
\text { legitimac } \\
\text { y }\end{array}$ & $\begin{array}{l}\text { Huma } \\
n \\
\text { rights }\end{array}$ & $\begin{array}{c}\text { Extern } \\
\text { al } \\
\text { interve } \\
\text { ntion }\end{array}$ & $\begin{array}{c}\text { DEMO } \\
\text { CRATI } \\
\text { C } \\
\text { DIMEN } \\
\text { SION }\end{array}$ & $\begin{array}{l}\text { Rule of } \\
\text { law }\end{array}$ & $\begin{array}{l}\text { Steering } \\
\text { capabilit } \\
y\end{array}$ & $\begin{array}{l}\text { Resou } \\
\text { rce } \\
\text { efficie } \\
\text { ncy }\end{array}$ & $\begin{array}{c}\text { Conse } \\
\text { nsus- } \\
\text { buildin } \\
\mathrm{g}\end{array}$ & $\begin{array}{c}\text { Interna } \\
\text { tional } \\
\text { cooper } \\
\text { ation }\end{array}$ & $\begin{array}{l}\text { GOVER } \\
\text { NANCE } \\
\text { DIMEN } \\
\text { SION }\end{array}$ & $\begin{array}{c}\text { Economi } \\
c \\
\text { inequalit } \\
y\end{array}$ & $\begin{array}{l}\text { Brain } \\
\text { drain } \\
\text { phenom } \\
\text { enon }\end{array}$ & $\begin{array}{l}\text { Public } \\
\text { servic } \\
\text { es }\end{array}$ & $\begin{array}{c}\text { Public } \\
\text { expenditur } \\
\text { e on } \\
\text { education } \\
\text { (\%GDP) }\end{array}$ & GDP & $\begin{array}{l}\text { Unempl } \\
\text { oyment } \\
\text { rate_15 } \\
\text { to } 24 \\
\text { years }\end{array}$ & $\begin{array}{l}\text { Labou } \\
\text { r } \\
\text { produ } \\
\text { ctivity } \\
\text { in } \\
\text { GDP } \\
\end{array}$ & $\begin{array}{c}\text { SOCIO- } \\
\text { ECONO } \\
\text { MIC } \\
\text { DIMENS } \\
\text { ION }\end{array}$ \\
\hline Political participation & 1.000 & 0.951 & 0.741 & -0.068 & -0.013 & -0.595 & 0.365 & 0.778 & 0.956 & 0.857 & 0.252 & 0.957 & 0.670 & 0.919 & -0.237 & 0.492 & -0.183 & 0.418 & 0.623 & 0.027 & 0.022 & 0.521 \\
\hline $\begin{array}{l}\text { Stability of democratic } \\
\text { institutions }\end{array}$ & 0.951 & 1.000 & 0.707 & 0.139 & 0.156 & -0.412 & 0.481 & 0.893 & 0.892 & 0.682 & 0.202 & 0.871 & 0.516 & 0.793 & -0.125 & 0.500 & 0.058 & 0.573 & 0.655 & -0.104 & 0.221 & 0.536 \\
\hline $\begin{array}{l}\text { Political and social } \\
\text { integration }\end{array}$ & 0.741 & 0.707 & 1.000 & -0.290 & -0.498 & -0.708 & -0.206 & 0.419 & 0.823 & 0.534 & -0.098 & 0.657 & 0.631 & 0.642 & -0.597 & 0.862 & -0.173 & 0.571 & 0.859 & 0.116 & -0.369 & 0.717 \\
\hline Security apparatus & -0.068 & 0.139 & -0.290 & 1.000 & 0.696 & 0.719 & 0.779 & 0.544 & -0.126 & -0.151 & 0.396 & -0.144 & -0.076 & -0.034 & 0.883 & -0.071 & 0.879 & -0.173 & 0.062 & 0.038 & 0.384 & 0.125 \\
\hline State legitimacy & -0.013 & 0.156 & -0.498 & 0.696 & 1.000 & 0.754 & 0.841 & 0.512 & -0.250 & -0.081 & 0.560 & -0.127 & -0.470 & -0.100 & 0.651 & -0.611 & 0.648 & -0.084 & -0.152 & -0.008 & 0.858 & -0.034 \\
\hline Human rights & -0.595 & -0.412 & -0.708 & 0.719 & 0.754 & 1.000 & 0.451 & 0.012 & -0.731 & -0.566 & 0.374 & -0.705 & -0.671 & -0.583 & 0.701 & -0.599 & 0.801 & -0.344 & -0.277 & 0.149 & 0.538 & -0.112 \\
\hline External intervention & 0.365 & 0.481 & -0.206 & 0.779 & 0.841 & 0.451 & 1.000 & 0.793 & 0.200 & 0.326 & 0.625 & 0.307 & 0.070 & 0.368 & 0.743 & -0.248 & 0.552 & -0.119 & 0.049 & 0.026 & 0.584 & 0.113 \\
\hline $\begin{array}{l}\text { DEMOCRATIC } \\
\text { DIMENSION }\end{array}$ & 0.778 & 0.893 & 0.419 & 0.544 & 0.512 & 0.012 & 0.793 & 1.000 & 0.664 & 0.559 & 0.465 & 0.660 & 0.363 & 0.672 & 0.290 & 0.281 & 0.434 & 0.337 & 0.569 & 0.021 & 0.405 & 0.529 \\
\hline Rule of law & 0.956 & 0.892 & 0.823 & -0.126 & -0.250 & -0.731 & 0.200 & 0.664 & 1.000 & 0.810 & 0.053 & 0.962 & 0.808 & 0.909 & -0.282 & 0.688 & -0.274 & 0.427 & 0.616 & -0.048 & -0.206 & 0.470 \\
\hline Steering capability & 0.857 & 0.682 & 0.534 & -0.151 & -0.081 & -0.566 & 0.326 & 0.559 & 0.810 & 1.000 & 0.511 & 0.857 & 0.781 & 0.969 & -0.127 & 0.284 & -0.329 & -0.082 & 0.455 & 0.371 & -0.231 & 0.454 \\
\hline Resource efficiency & 0.252 & 0.202 & -0.098 & 0.396 & 0.560 & 0.374 & 0.625 & 0.465 & 0.053 & 0.511 & 1.000 & 0.105 & 0.124 & 0.413 & 0.403 & -0.327 & 0.394 & -0.517 & 0.288 & 0.768 & 0.176 & 0.495 \\
\hline Consensus-building & 0.957 & 0.871 & 0.657 & -0.144 & -0.127 & -0.705 & 0.307 & 0.660 & 0.962 & 0.857 & 0.105 & 1.000 & 0.752 & 0.918 & -0.205 & 0.483 & -0.368 & 0.347 & 0.422 & -0.120 & -0.080 & 0.292 \\
\hline $\begin{array}{l}\text { International } \\
\text { cooperation }\end{array}$ & 0.670 & 0.516 & 0.631 & -0.076 & -0.470 & -0.671 & 0.070 & 0.363 & 0.808 & 0.781 & 0.124 & 0.752 & 1.000 & 0.854 & -0.059 & 0.691 & -0.312 & -0.092 & 0.448 & 0.222 & -0.652 & 0.369 \\
\hline $\begin{array}{l}\text { GOVERNANCE } \\
\text { DIMENSION }\end{array}$ & 0.919 & 0.793 & 0.642 & -0.034 & -0.100 & -0.583 & 0.368 & 0.672 & 0.909 & 0.969 & 0.413 & 0.918 & 0.854 & 1.000 & -0.082 & 0.464 & -0.229 & 0.052 & 0.550 & 0.263 & -0.239 & 0.505 \\
\hline Economic inequality & -0.237 & -0.125 & -0.597 & 0.883 & 0.651 & 0.701 & 0.743 & 0.290 & -0.282 & -0.127 & 0.403 & -0.205 & -0.059 & -0.082 & 1.000 & -0.334 & 0.619 & -0.514 & -0.327 & 0.028 & 0.275 & -0.226 \\
\hline $\begin{array}{l}\text { Brain drain } \\
\text { phenomenon }\end{array}$ & 0.492 & 0.500 & 0.862 & -0.071 & -0.611 & -0.599 & -0.248 & 0.281 & 0.688 & 0.284 & -0.327 & 0.483 & 0.691 & 0.464 & -0.334 & 1.000 & -0.052 & 0.451 & 0.693 & -0.039 & -0.560 & 0.520 \\
\hline Public services & -0.183 & 0.058 & -0.173 & 0.879 & 0.648 & 0.801 & 0.552 & 0.434 & -0.274 & -0.329 & 0.394 & -0.368 & -0.312 & -0.229 & 0.619 & -0.052 & 1.000 & -0.021 & 0.280 & 0.204 & 0.419 & 0.369 \\
\hline $\begin{array}{l}\text { Public expenditure on } \\
\text { education (\%GDP) }\end{array}$ & 0.418 & 0.573 & 0.571 & -0.173 & -0.084 & -0.344 & -0.119 & 0.337 & 0.427 & -0.082 & -0.517 & 0.347 & -0.092 & 0.052 & -0.514 & 0.451 & -0.021 & 1.000 & 0.392 & -0.586 & 0.343 & 0.187 \\
\hline GDP & 0.623 & 0.655 & 0.859 & 0.062 & -0.152 & -0.277 & 0.049 & 0.569 & 0.616 & 0.455 & 0.288 & 0.422 & 0.448 & 0.550 & -0.327 & 0.693 & 0.280 & 0.392 & 1.000 & 0.440 & -0.190 & 0.965 \\
\hline $\begin{array}{l}\text { Unemployment } \\
\text { rate_ } 15 \text { to } 24 \text { years }\end{array}$ & 0.027 & -0.104 & 0.116 & 0.038 & -0.008 & 0.149 & 0.026 & 0.021 & -0.048 & 0.371 & 0.768 & -0.120 & 0.222 & 0.263 & 0.028 & -0.039 & 0.204 & -0.586 & 0.440 & 1.000 & -0.365 & 0.642 \\
\hline $\begin{array}{l}\text { Labour productivity in } \\
\text { GDP }\end{array}$ & 0.022 & 0.221 & -0.369 & 0.384 & 0.858 & 0.538 & 0.584 & 0.405 & -0.206 & -0.231 & 0.176 & -0.080 & -0.652 & -0.239 & 0.275 & -0.560 & 0.419 & 0.343 & -0.190 & -0.365 & 1.000 & -0.166 \\
\hline $\begin{array}{l}\text { SOCIO-ECONOMIC } \\
\text { DIMENSION }\end{array}$ & 0.521 & 0.536 & 0.717 & 0.125 & -0.034 & -0.112 & 0.113 & 0.529 & 0.470 & 0.454 & 0.495 & 0.292 & 0.369 & 0.505 & -0.226 & 0.520 & 0.369 & 0.187 & 0.965 & 0.642 & -0.166 & 1.000 \\
\hline
\end{tabular}

Source: authors' estimates 


\section{Annex 1b. Correlation matrix - 2020}

\begin{tabular}{|c|c|c|c|c|c|c|c|c|c|c|c|c|c|c|c|c|c|c|c|c|c|c|}
\hline VARIABLES & $\begin{array}{c}\text { Politic } \\
\text { al } \\
\text { partici } \\
\text { pation }\end{array}$ & $\begin{array}{c}\text { Stability } \\
\text { of } \\
\text { democrat } \\
\text { ic } \\
\text { institution } \\
\text { s }\end{array}$ & $\begin{array}{l}\text { Politic } \\
\text { al and } \\
\text { social } \\
\text { integr } \\
\text { ation }\end{array}$ & $\begin{array}{c}\text { Security } \\
\text { apparatu } \\
\text { S }\end{array}$ & $\begin{array}{c}\text { State } \\
\text { legitim } \\
\text { acy }\end{array}$ & $\begin{array}{l}\text { Human } \\
\text { rights }\end{array}$ & $\begin{array}{c}\text { Extern } \\
\text { al } \\
\text { interve } \\
\text { ntion }\end{array}$ & $\begin{array}{c}\text { DEMO } \\
\text { CRATI } \\
\text { C } \\
\text { DIMEN } \\
\text { SION }\end{array}$ & $\begin{array}{l}\text { Rule of } \\
\text { law }\end{array}$ & $\begin{array}{c}\text { Steering } \\
\text { capabilit } \\
y\end{array}$ & $\begin{array}{l}\text { Resour } \\
\text { ce } \\
\text { efficien } \\
\text { cy }\end{array}$ & $\begin{array}{c}\text { Consens } \\
\text { us- } \\
\text { building }\end{array}$ & $\begin{array}{c}\text { Internat } \\
\text { ional } \\
\text { cooper } \\
\text { ation }\end{array}$ & $\begin{array}{c}\text { GOVE } \\
\text { RNAN } \\
\text { CE } \\
\text { DIME } \\
\text { NSIO } \\
\text { N }\end{array}$ & $\begin{array}{c}\text { Economi } \\
c \\
\text { inequalit } \\
y\end{array}$ & $\begin{array}{l}\text { Brain } \\
\text { drain } \\
\text { phenom } \\
\text { enon }\end{array}$ & $\begin{array}{c}\text { Public } \\
\text { services }\end{array}$ & $\begin{array}{c}\text { Public } \\
\text { expendit } \\
\text { ure on } \\
\text { educatio } \\
n \\
(\% \mathrm{GDP})\end{array}$ & GDP & $\begin{array}{c}\text { Unemplo } \\
\text { yment } \\
\text { rate_15 } \\
\text { to } 24 \\
\text { years }\end{array}$ & $\begin{array}{l}\text { Labour } \\
\text { producti } \\
\text { vity in } \\
\text { GDP }\end{array}$ & $\begin{array}{l}\text { SOCIO } \\
-- \\
\text { ECON } \\
\text { OMIC } \\
\text { DIMEN } \\
\text { SION }\end{array}$ \\
\hline Political participation & 1.000 & 0.965 & 0.925 & 0.137 & -0.563 & -0.745 & 0.374 & 0.908 & 0.958 & 0.859 & 0.852 & 0.966 & 0.861 & 0.981 & -0.546 & 0.682 & -0.329 & -0.098 & 0.783 & 0.736 & 0.525 & 0.967 \\
\hline $\begin{array}{l}\text { Stability of democratic } \\
\text { institutions }\end{array}$ & 0.965 & 1.000 & 0.932 & 0.295 & -0.634 & -0.792 & 0.535 & 0.923 & 0.927 & 0.878 & 0.874 & 0.913 & 0.803 & 0.957 & -0.606 & 0.716 & -0.138 & 0.101 & 0.850 & 0.541 & 0.443 & 0.927 \\
\hline $\begin{array}{l}\text { Political and social } \\
\text { integration }\end{array}$ & 0.925 & 0.932 & 1.000 & 0.079 & -0.800 & -0.715 & 0.415 & 0.826 & 0.881 & 0.746 & 0.700 & 0.902 & 0.622 & 0.853 & -0.799 & 0.782 & -0.233 & 0.078 & 0.929 & 0.521 & 0.200 & 0.943 \\
\hline Security apparatus & 0.137 & 0.295 & 0.079 & 1.000 & 0.169 & 0.092 & 0.804 & 0.513 & 0.290 & 0.453 & 0.395 & -0.066 & 0.344 & 0.276 & -0.143 & -0.197 & 0.201 & 0.251 & 0.043 & -0.182 & 0.218 & -0.037 \\
\hline State legitimacy & -0.563 & -0.634 & -0.800 & 0.169 & 1.000 & 0.628 & -0.141 & -0.374 & -0.424 & -0.429 & -0.241 & -0.646 & -0.131 & -0.431 & 0.753 & -0.907 & -0.214 & -0.231 & -0.943 & -0.071 & 0.345 & -0.711 \\
\hline Human rights & -0.745 & -0.792 & -0.715 & 0.092 & 0.628 & 1.000 & -0.261 & -0.539 & -0.614 & -0.530 & -0.738 & -0.791 & -0.517 & -0.706 & 0.338 & -0.752 & -0.063 & -0.338 & -0.734 & -0.324 & -0.408 & -0.769 \\
\hline External intervention & 0.374 & 0.535 & 0.415 & 0.804 & -0.141 & -0.261 & 1.000 & 0.669 & 0.550 & 0.392 & 0.649 & 0.154 & 0.315 & 0.443 & -0.548 & -0.020 & -0.059 & 0.616 & 0.321 & -0.133 & 0.283 & 0.201 \\
\hline $\begin{array}{l}\text { DEMOCRATIC } \\
\text { DIMENSION } \\
\end{array}$ & 0.908 & 0.923 & 0.826 & 0.513 & -0.374 & -0.539 & 0.669 & 1.000 & 0.966 & 0.879 & 0.888 & 0.777 & 0.863 & 0.944 & -0.573 & 0.429 & -0.326 & 0.005 & 0.648 & 0.592 & 0.553 & 0.794 \\
\hline Rule of law & 0.958 & 0.927 & 0.881 & 0.290 & -0.424 & -0.614 & 0.550 & 0.966 & 1.000 & 0.806 & 0.894 & 0.855 & 0.846 & 0.960 & -0.606 & 0.475 & -0.479 & -0.026 & 0.671 & 0.705 & 0.587 & 0.865 \\
\hline Steering capability & 0.859 & 0.878 & 0.746 & 0.453 & -0.429 & -0.530 & 0.392 & 0.879 & 0.806 & 1.000 & 0.719 & 0.817 & 0.898 & 0.903 & -0.347 & 0.620 & 0.004 & -0.246 & 0.687 & 0.590 & 0.417 & 0.820 \\
\hline Resource efficiency & 0.852 & 0.874 & 0.700 & 0.395 & -0.241 & -0.738 & 0.649 & 0.888 & 0.894 & 0.719 & 1.000 & 0.734 & 0.828 & 0.905 & -0.362 & 0.351 & -0.317 & 0.213 & 0.515 & 0.538 & 0.778 & 0.713 \\
\hline Consensus-building & 0.966 & 0.913 & 0.902 & -0.066 & -0.646 & -0.791 & 0.154 & 0.777 & 0.855 & 0.817 & 0.734 & 1.000 & 0.798 & 0.921 & -0.467 & 0.807 & -0.231 & -0.185 & 0.817 & 0.744 & 0.426 & 0.993 \\
\hline $\begin{array}{l}\text { International } \\
\text { cooperation }\end{array}$ & 0.861 & 0.803 & 0.622 & 0.344 & -0.131 & -0.517 & 0.315 & 0.863 & 0.846 & 0.898 & 0.828 & 0.798 & 1.000 & 0.931 & -0.134 & 0.388 & -0.302 & -0.344 & 0.437 & 0.802 & 0.754 & 0.761 \\
\hline $\begin{array}{l}\text { GOVERNANCE } \\
\text { DIMENSION }\end{array}$ & 0.981 & 0.957 & 0.853 & 0.276 & -0.431 & -0.706 & 0.443 & 0.944 & 0.960 & 0.903 & 0.905 & 0.921 & 0.931 & 1.000 & -0.443 & 0.585 & -0.306 & -0.110 & 0.694 & 0.733 & 0.631 & 0.911 \\
\hline Economic inequality & -0.546 & -0.606 & -0.799 & -0.143 & 0.753 & 0.338 & -0.548 & -0.573 & -0.606 & -0.347 & -0.362 & -0.467 & -0.134 & -0.443 & 1.000 & -0.482 & 0.232 & -0.352 & -0.758 & -0.087 & 0.212 & -0.561 \\
\hline Brain drain phenomenon & 0.682 & 0.716 & 0.782 & -0.197 & -0.907 & -0.752 & -0.020 & 0.429 & 0.475 & 0.620 & 0.351 & 0.807 & 0.388 & 0.585 & -0.482 & 1.000 & 0.275 & -0.009 & 0.921 & 0.294 & -0.108 & 0.830 \\
\hline Public services & -0.329 & -0.138 & -0.233 & 0.201 & -0.214 & -0.063 & -0.059 & -0.326 & -0.479 & 0.004 & -0.317 & -0.231 & -0.302 & -0.306 & 0.232 & 0.275 & 1.000 & 0.266 & 0.120 & -0.657 & -0.495 & -0.218 \\
\hline $\begin{array}{l}\text { Public expenditure on } \\
\text { education }(\% \mathrm{GDP})\end{array}$ & -0.098 & 0.101 & 0.078 & 0.251 & -0.231 & -0.338 & 0.616 & 0.005 & -0.026 & -0.246 & 0.213 & -0.185 & -0.344 & -0.110 & -0.352 & -0.009 & 0.266 & 1.000 & 0.172 & -0.638 & -0.108 & -0.148 \\
\hline GDP & 0.783 & 0.850 & 0.929 & 0.043 & -0.943 & -0.734 & 0.321 & 0.648 & 0.671 & 0.687 & 0.515 & 0.817 & 0.437 & 0.694 & -0.758 & 0.921 & 0.120 & 0.172 & 1.000 & 0.269 & -0.067 & 0.868 \\
\hline $\begin{array}{l}\text { Unemployment rate_15 } \\
\text { to } 24 \text { years }\end{array}$ & 0.736 & 0.541 & 0.521 & -0.182 & -0.071 & -0.324 & -0.133 & 0.592 & 0.705 & 0.590 & 0.538 & 0.744 & 0.802 & 0.733 & -0.087 & 0.294 & -0.657 & -0.638 & 0.269 & 1.000 & 0.642 & 0.699 \\
\hline $\begin{array}{l}\text { Labour productivity in } \\
\text { GDP }\end{array}$ & 0.525 & 0.443 & 0.200 & 0.218 & 0.345 & -0.408 & 0.283 & 0.553 & 0.587 & 0.417 & 0.778 & 0.426 & 0.754 & 0.631 & 0.212 & -0.108 & -0.495 & -0.108 & -0.067 & 0.642 & 1.000 & 0.345 \\
\hline $\begin{array}{l}\text { SOCIO-ECONOMIC } \\
\text { DIMENSION }\end{array}$ & 0.967 & 0.927 & 0.943 & -0.037 & -0.711 & -0.769 & 0.201 & 0.794 & 0.865 & 0.820 & 0.713 & 0.993 & 0.761 & 0.911 & -0.561 & 0.830 & -0.218 & -0.148 & 0.868 & 0.699 & 0.345 & 1.000 \\
\hline
\end{tabular}

Source: authors' estimates 